\title{
Possible Use of Foresight, Understanding, and Planning by Wolves Hunting Muskoxen
}

\author{
L. DAVID MECH ${ }^{1}$
}

\author{
(Received 20 September 2006; accepted in revised form 18 December 2006)
}

\begin{abstract}
On Ellesmere Island in 2006, arctic wolves (Canis lupus arctos) were observed making a two-pronged approach to a herd of muskoxen (Ovibos moschatus) and, on another occasion, ambushing muskoxen. Both observations seemed to provide evidence that the wolves were using foresight, understanding, and planning. Although the possible use of insight and purposiveness has been documented in captive wolves, the present report is one of the few to document the possibility that freeranging wolves use these other three mental processes.
\end{abstract}

Key words: Canis lupus, cooperative hunting, foresight in wolves, muskoxen, Ovibos moschatus, planning in wolves, strategy, understanding in wolves, wolf

RÉSUMÉ. En 2006, sur l'île Ellesmere, des loups arctiques (Canis lupus arctos) ont été observés en train d'approcher sur deux fronts un troupeau de bœufs musqués (Ovibos moschatus) et une autre fois, en train de tendre une embuscade à des bœufs musqués. Ces deux observations portent à croire que les loups sont en mesure de prévoir, de comprendre et de planifier. Bien que le recours possible à la prévoyance et à l'intentionnalité ait été officiellement remarqué chez les loups en captivité, le présent rapport est l'un des rares documents énonçant la possibilité que les loups en liberté aient recours à ces processus mentaux.

Mots clés : Canis lupus, chasse coopérative, prévoyance chez les loups, bœufs musqués, Ovibos moschatus, planification chez les loups, stratégie, compréhension chez les loups, loup

Traduit pour la revue Arctic par Nicole Giguère.

\section{INTRODUCTION}

Since wolves (Canis lupus) live primarily in packs and usually hunt prey larger than themselves, the question arises as to what degree of higher mental processing wolves are capable of during their hunts. Fox (1971) reported two instances of captive wolves' behaving in ways that he thought showed "insight and purposiveness," but which also seemed to me to show foresight and understanding. Packard (2003) summarized studies of wolf intelligence and learning abilities, but the only high-order mental process she attributed to wolves was insight. Peterson and Ciucci (2003:121) discussed "strategic cooperation" in wolves hunting prey and defined cooperative hunting as "conducting the hunt or chase in such a way as to capture the prey more effectively than by merely running after it as a group." The authors listed ambushing, heading off fleeing prey, or relay running as examples of strategic cooperation. These examples seem to imply use of foresight, understanding, and planning. However, it is not clear whether there are many good examples of wolves using such strategies and mental processes.

Peterson and Ciucci (2003:122) summarized the findings of a poll on the subject as follows:
A survey of 19 biologists who have observed many wolfprey encounters reveals no unanimity in their beliefs about the wolf's possible use of ambushing or relay running ... Most wolf biologists believed that wolves do sometimes use some forms of cooperative strategy, but the number of descriptions including convincing examples of it is low. Most described chases were simple and straightforward.

Peterson and Ciucci (2003) also cited several published observations of wolves hunting various prey but concluded that the authors they cited "made little mention of the wolves' use of cooperative maneuvers." Nevertheless, older literature does seem to document ambushing (Kelsall, 1968; Rutter and Pimlott, 1968; Clark, 1971; Haber, 1977), and Mech (1995) cited several observations of yearling wolves chasing arctic hares (Lepus arcticus) toward waiting adults. Gunn et al. (2006:7) report second-hand on observations of a possible "specialized hunting strategy" used by wolves: chasing caribou over a cliff.

Studies of other carnivores that hunt in groups (Estes and Goddard, 1967; Kruuk, 1972; Packer and Ruttan, 1988; Mills, 1990; Scheel and Packer, 1991; Caro, 1994; Creel and Creel, 1995, 2002) have published no specific

\footnotetext{
${ }^{1}$ U.S. Geological Survey, Northern Prairie Wildlife Research Center, 8711 - 37th Street SE, Jamestown, North Dakota 58401-7317, USA; mailing address: The Raptor Center, 1920 Fitch Avenue, University of Minnesota, St. Paul, Minnesota 55108, USA; david_mech@usgs.gov or mechx002@umn.edu

(C) The Arctic Institute of North America
} 
observations that suggest higher-order strategies, except possibly those of African lions (Panthera leo) reported by Schaller (1972:248-250). However, Schaller expressed some doubt about how truly cooperative the hunts he cited were. Given this apparent disagreement about the subject in relation to wolves and the almost total lack of relevant published observations of similar behavior in other social carnivores, there is a need to document wolf hunts that appear to involve foresight (behaving appropriately for dealing with a future event), understanding (comprehending complex relationships), and planning (deciding to behave in a way that considers information relevant to a perceived outcome). Here I describe two such wolf hunts of muskoxen (Ovibos moschatus).

\section{STUDY AREA}

This study was conducted on the Fosheim Peninsula on the west side of Ellesmere Island, Nunavut, Canada $\left(80^{\circ} \mathrm{N}\right.$, $\left.86^{\circ} \mathrm{W}\right)$. The area includes hills, lowlands, creek bottoms, ridges, and considerable uneven terrain with many dips and trenches. Unlike much of the surrounding region, this area is generally free of permanent snow and ice in summer, and it contains rock, gravel, bare soil, and scattered tundra and northern wetland vegetation. Wolves, muskoxen, and arctic hares are common in the area (Tener, 1954). Wolves have denned in this region for decades-or possibly centuries (Parmelee, 1964; Grace, 1976; Mech, 1987; Mech and Packard, 1990). The main foods of the wolves are muskoxen (especially calves during summer), arctic hares (Tener, 1954), and occasionally seals (Phoca spp.).

Wolves in the study area have long been unafraid of humans (Parmelee, 1964; Grace, 1976), and during the present study, a pack of seven adults and five pups allowed me to observe them around their den, as an earlier pack had done from 1986 through 1996 (Mech, 1995, 1997). The progenitors of the present wolves colonized the study area in 2003, after the last member of the previous pack had disappeared between the summers of 2000 and 2001 (Mech, 2005). Although I could not definitely identify individual members of the present pack from year to year, the distinctive behavior and general appearance of the breeding male made me confident that it was the same animal from 2003 through 2006. The breeding pair produced four pups in 2004 , and the pack consisted of six adults in 2005, suggesting that all four pups had survived. The pack produced three pups in 2005, so in 2006, the additional five members (besides the breeding pair) could have consisted of any combination of animals born in 2004 or 2005.

\section{METHODS}

As in previous years, I and one to three associates sat on all-terrain vehicles on a hillside within $50 \mathrm{~m}$ of the wolves' den from 1 July through 12 July 2006 and observed the wolves and their pups. The view from that area also allowed me to observe areas below for several kilometers to the northeast and east. Muskox herds in that area are obvious to the naked human eye from as far as about $5 \mathrm{~km}$ away, and several summers of observation from the same location (Mech, 1987, 1997) have shown me that wolves can see muskoxen from the same spot for at least the same distance. I made the present observations from near the den through electronically stabilized $15 \times$ binoculars.

\section{DESCRIPTIONS OF OBSERVATIONS}

The following descriptions are edited versions of my field notes:

2 July (Fig. 1) - At about 2240 hours, one wolf started heading north and along ridges, and each wolf eventually followed it. There had been a howl and some whines, but no rally or chorus howl. All seven wolves headed north, jumped two hares but did not chase them (which was unusual), and continued on to the northeast, where a herd of seven adult muskoxen and three calves was located upwind of the wolves and $3-5 \mathrm{~km}$ from the den. We could see the herd from where we and the wolves had been, so presumably the wolves had also seen the muskoxen from the den area. The wolves disappeared until about 2250 , when we saw two wolves about $200 \mathrm{~m}$ from the muskoxen heading toward them up a shallow valley, slowly stalking. At least four other wolves were watching intently from a ridge of rock piles approximately $400 \mathrm{~m}$ from the muskoxen. Suddenly the muskoxen ran to each other, two to three muskoxen that were lying down arose, and all grouped up. Then all the wolves, both waiters and stalkers, rushed to the herd, their movement apparently triggered by the running of the muskoxen. The wolves milled around the herd for about one minute, then left and continued north.

On 6 July 2006, I was watching a breeding pair of wolves, three to four subadults, and five pups around the den. A subadult had returned at 1430 carrying the head of a muskox calf. The breeding male then returned to the den from the same direction at 1702 hours, his left hind leg covered with fresh blood. I concluded that the two were returning from a successful muskox hunt. Meanwhile, a herd of about 13 adult muskoxen and seven calves had come into clear view about $1.6 \mathrm{~km}$ northeast of the den.

1628 hours - Male subordinate Wolf A, while on a ridge just east of the den, stared intently toward the muskoxen for one to two minutes. He then headed to another subadult wolf (Wolf B) of unknown identity, which was lying about $20 \mathrm{~m}$ away below the ridge chewing on an object, and "nosed" that wolf. They were too far away for me to hear whether either made any sound, but Wolf B immediately abandoned the object, went to where Wolf A 




FIG. 1. Diagram of the hunt of muskoxen by seven arctic wolves observed on Ellesmere Island on 2 July 2006. Bold arrows represent the approximate paths of six wolves and their direction (the path of one wolf was unknown). Long, irregular lines indicate uneven terrain, and the short, curved lines outline the valley along which two wolves traveled.

had stared toward the muskoxen, and also stared toward them. It appeared that Wolf A had communicated with Wolf B, motivating Wolf B to look toward the muskoxen.

2025 hours - Two wolves, Wolf A and a wolf that was either Wolf B or one of two other possible subadults, had gone down the den valley and then up onto the flats to within $300 \mathrm{~m}$ south of the muskoxen (Fig. 2). The wolves had moved around $200 \mathrm{~m}$ on the flats toward the muskoxen when they stopped, stared toward the herd for a few minutes, and then backtracked about $50 \mathrm{~m}$. They headed east about $100 \mathrm{~m}$ and then back north about $50 \mathrm{~m}$, moving toward the muskoxen along a parallel to their original route. They then lay down out of sight, about $100 \mathrm{~m}$ from a green, wet sedge meadow about $15 \mathrm{~m}$ wide and $40 \mathrm{~m}$ long, still about $300 \mathrm{~m}$ from the herd. (One adult muskox stood around $200 \mathrm{~m}$ southeast of them, possibly having passed from the herd through the area where the wolves now stood before the wolves' arrival.)

2034 hours - The two wolves were lying hidden around $200 \mathrm{~m}$ southeast of the muskoxen; the muskoxen grouped up loosely, but by 2042 hours had resumed feeding.

2104 hours - Three adult muskoxen meandered down the meadow near the wolves. When the first was within around $30 \mathrm{~m}$ of the wolves, the wolves left, traveling around $30 \mathrm{~m}$ south down a trench. They circled west and lay down in a hidden spot around 15-30 m from the meadow, in rough, uneven terrain with lots of trenches and small hillocks (1 $\mathrm{m}$ high). The muskoxen did not appear to sense the wolves and continued southeast. The herd, some $200 \mathrm{~m}$ away, lay down. We continued to watch from the den with $15 \times$ stabilizer binoculars. The muskoxen



FIG. 2. Diagram of 6 July 2006 hunt of muskoxen by two arctic wolves on Ellesmere Island. Bold arrows represent the paths and direction of the two wolves and the muskoxen, and short diagonal marks indicate the low valley through which the wolves traveled. A - hill from which wolves appeared to see muskoxen at 1629 hours; B - wolf den; C - valley down which two wolves began traveling at 2025 hours; D - point where wolves waited from 2034 to 2342 hours; E - muskox herd; F - meadow to which muskoxen traveled and where wolves confronted them.

and wolves remained where they were for three hours. At least one of the wolves intermittently lifted its head and apparently was watching the muskoxen.

2330 hours - The muskoxen began to arise.

2337 hours - The muskoxen grouped momentarily (30 seconds) and then opened the group again and began drifting southeast along the same general route as the first three adults.

2342 hours - The muskoxen got to within $100 \mathrm{~m}$ of the wolves, which then circled east and then north up the trench and charged the muskoxen from about $50 \mathrm{~m}$. The muskoxen grouped, and the wolves milled around about $30 \mathrm{~m}$ away for one to two minutes, then left and lay down around $60 \mathrm{~m}$ from herd. After around two minutes, the muskoxen continued drifting southeast. The wolves arose and muskoxen grouped for one minute and traveled on. The two wolves lay back down and slept. We left at 1207 hours, when the muskoxen were $400 \mathrm{~m}$ southeast of the wolves.

\section{DISCUSSION}

Muskoxen, which live in herds and possess formidable horns and hooves, are presumably especially challenging for wolves to overcome. During summer, wolves try to focus as much as possible on capturing the less dangerous calves. However, the calves seek the protection of the adults by remaining close to them, and the adults group 
around the calves or in front of them when they detect wolves. Thus it would benefit wolves to evolve special strategies to aid in overcoming muskox defenses.

Of a total 19 observations that I made from 1986 to 2006 of at least two wolves hunting muskoxen, the two described above were the only ones that involved behavior suggesting higher-order mental processing. During the other observations, the wolves generally tried to approach the muskoxen slowly, sometimes using uneven terrain to obscure themselves, and then charged the muskoxen. It may be relevant that the two hunts described above were the only two I have observed that involved the current wolf pack. The other 17 observations all involved a pack that had died out by 2001 (Mech, 2005). During both observations in this study, the wolves appeared to be using at least elementary cooperation and strategy (Peterson and Ciucci, 2003) and showing both insight and purposiveness (Fox, 1971). Fox (1971) did not define these terms, but I would define insight as the perceiving of a solution, and purposiveness as deliberate behavior with an objective. The observations also seemed to show foresight, understanding, and planning (defined above).

The wolves observed on 2 July 2006 demonstrated all these traits by splitting up, approaching the muskoxen from two directions, and using different behaviors, waiting and watching by most of the pack and sneaking up by two members. Had the approaching wolves succeeded in forcing the muskoxen to run, the waiting wolves might have been able to intercept them in ambush or at least could have attacked them from a different direction.

The wolves observed on 6 July showed two behaviors that suggested foresight, understanding, and planning. The first was the apparent communication by Wolf A to Wolf B that led Wolf B to drop a play object, travel about $20 \mathrm{~m}$ to the top of a ridge, and stare intently toward the same muskox herd with seven calves that Wolf $A$ had just stared toward, along with the approach of Wolf A (and possibly Wolf B) to the muskoxen four hours later.

The second behavior was the manner in which the two wolves approached the muskoxen. The wolves traveled down a shallow valley out of sight of the muskoxen and then up the side of the valley to some uneven flats within about $300 \mathrm{~m}$ of the muskoxen, where they stopped for a few minutes and stared at the herd. Rather than continuing to approach the herd directly, or even lying down and waiting where they were or farther along in the same direction, they then backtracked, looped around to a new area, and hid in a depression near the type of area where muskoxen often feed. When an adult muskox approached the area, the wolves appeared to sneak back away from the area, and they repositioned themselves where they seemed to be better hidden. In summer the wolves usually kill calves, and approaching or being discovered by the adult muskox would have precluded an attack on the herd's calves. There they waited for about three hours, intermittently popping up and looking toward the muskoxen.
This waiting-in-ambush behavior implies that the wolves expected the muskoxen to become available eventually and that they understood that waiting in hiding would improve their chances of getting nearer to the muskoxen. It is even possible that the wolves chose a hiding place that was near a meadow they expected the muskoxen to visit. When the wolves first saw the muskoxen hours before, the herd had been traveling west, yet the wolves positioned themselves southeast of the herd. When the wolves first started toward the herd, I could not have predicted which direction the herd would move. There was an adult muskox some $400 \mathrm{~m}$ southeast of the herd, which might have split from the herd without my having seen it, and possibly this animal provided the clue for the wolves to position themselves correctly. If so, that strategy also implied foresight, understanding, and planning. If they did not take their clue from the single adult, perhaps the wolves associated the meadow with the type of terrain muskoxen choose for their travel routes, also demonstrating the same mental processes.

In any case, the strategy worked. After a thee-hour wait, the muskox herd traveled to within $100 \mathrm{~m}$ of the hidden wolves, and the wolves charged them. The muskoxen, however, still detected the wolves in time and were able to group defensively, protecting all seven calves. The wolves quickly gave up.

Most published reports of the mental abilities of wolves have been based on observations and tests of captive wolves, as summarized by Packard (2003). As valuable and necessary as such approaches are, they fail to measure the wolf's abilities under natural conditions, where the animals must apply those abilities to survive. However, the circumstances of observing wolves in the wild-especially during their long hunting sessions, when both predator and prey may cover great distances-make detecting wolf mental capabilities under those conditions most difficult. Often only parts of hunts are observed, and sometimes they are observed from circling aircraft. In many cases, for example with wolves hunting deer (Odocoileus virginianus) or moose (Alces alces), the wolves' only possible, or most logical, approach is direct, and no special strategy would be effective or possible. These facts may explain why few hunts involving strategy have been documented. Even those described by Mech (1995) involved wolves in the present study area, where conditions for observing wolves hunting are especially favorable.

Nevertheless, the observations that have accumulated over the years (Kelsall, 1968; Rutter and Pimlott, 1968; Clark, 1971; Haber, 1977; Mech, 1995 and the present study) do suggest that, when possible and necessary, wolves are capable of employing higher mental processes in their hunting. It is likely that a group of wolves with considerable experience hunting together, through which they could learn each other's usual hunting approaches under various conditions, could more easily use the specialized strategies (ambushing behaviour and split approach) that I observed in July 2006 on Ellesmere Island. The hunting groups I reported in Mech (1995) and observed in 2006 
both consisted of parent wolves and their offspring, oneyear-olds in the first case and one- and two-year-olds in the second. Since offspring join parents in hunting at about six months of age, such strategic cooperation as chasing into ambush can apparently be learned within about eight months.

Clearly it is difficult to distinguish between an observer's perception and interpretation of observations such as these and the actual existence of higher-order behavior in the animals involved, and I might have overinterpreted the significance of the behavior. However, it is only by airing such observations that science can arrive at the proper interpretations.

\section{ACKNOWLEDGEMENTS}

This study was supported by the U.S. Geological Survey. Environment Canada and the Polar Continental Shelf Project (PCSP), Natural Resources Canada, provided logistical support, for which I am also grateful. The Department of Environment, Nunavut, issued the research permit. This is PCSP paper 024-06.

\section{REFERENCES}

CARO, T.M. 1994. Cheetahs of the Serengeti Plains: Group living in an associated species. Illinois: The University of Chicago Press.

CLARK, K.R.F. 1971. Food habits and behavior of the tundra wolf on central Baffin Island. PhD dissertation, University of Toronto, Toronto, Ontario.

CREEL, S., and CREEL, N.M. 1995. Communal hunting and pack size in African wild dogs, Lycaon pictus. Animal Behaviour 50:1325-1339.

— 2002. The African wild dog: Behavior, ecology, and conservation. Princeton, New Jersey: Princeton University Press. $341 \mathrm{p}$.

ESTES, R.D., and GOODARD, R.D. 1967. Prey selection and hunting behavior of the African wild dog. Journal of Wildlife Management 31:52-70.

FOX, M.W. 1971. Possible examples of high-order behavior in wolves. Journal of Mammalogy 52:611.

GRACE, E.S. 1976. Interactions between men and wolves at an Arctic outpost on Ellesmere Island. Canadian Field-Naturalist 90:149-156.
GUNN, A., MILLER, F.L., BARRY, S.J., and BUCHAN, A. 2006. A near-total decline in caribou on Prince of Wales, Somerset, and Russell islands, Canadian Arctic. Arctic 59:1-13.

HABER, G.C. 1977. Socio-ecological dynamics of wolves and prey in a Subarctic ecosystem. PhD dissertation, University of British Columbia, Vancouver, British Columbia. 824 p.

KELSALL, J.P. 1968. The migratory barren ground caribou of Canada. Ottawa: Canadian Wildlife Service, Queen's Printer. $340 \mathrm{p}$.

KRUUK, H. 1972. The spotted hyena. Chicago: University of Chicago Press. 335 p.

MECH, L.D. 1987. At home with the arctic wolf. National Geographic 171:562-593.

-1995. A ten-year history of the demography and productivity of an arctic wolf pack. Arctic 48:329-332.

. 1997. The arctic wolf: Ten years with the pack. Stillwater, Minnesota: Voyageur Press. 144 p.

. 2005. Decline and recovery of a High Arctic wolf-prey system. Arctic 58:305-307.

MECH, L.D., and PACKARD, J.M. 1990. Possible use of wolf (Canis lupus) den over several centuries. Canadian FieldNaturalist 104:484-485.

MILLS, M.G.L. 1990. Kalahari hyaenas: The comparative behavioural ecology of two species. London: Unwin Hyman. $304 \mathrm{p}$.

PACKARD, J.M. 2003. Wolf behavior: Reproductive, social and intelligent. In: Mech, L.D., and Boitani, L., eds. Wolves: behavior, ecology, and conservation. Chicago: University of Chicago Press. 35-65.

PACKER, C., and RUTTAN, L. 1988. The evolution of cooperative hunting. The American Naturalist 132:159-198.

PARMELEE, D.F. 1964. Myth of the wolf. The Beaver 295:4-9. PETERSON, R.O., and CIUCCI, P. 2003. The wolf as a carnivore. In: Mech, L.D., and Boitani, L., eds. Wolves: behavior, ecology, and conservation. Chicago: University of Chicago Press. $104-130$.

RUTTER, R.J., and PIMLOTT, D.H. 1968. The world of the wolf. Philadelphia: J.B. Lippincott Company. 202 p.

SCHALLER, G.B. 1972. The Serengeti lion: A study of predatorprey relations. Chicago: University of Chicago Press. 480 p.

SCHEEL, D., and PACKER, C. 1991. Group hunting behaviour of lions: A search for cooperation. Animal Behaviour 41: 697-709.

TENER, J.S. 1954. A preliminary study of the musk-oxen of Fosheim Peninsula, N.W.T. Canadian Wildlife Service Wildlife Management Bulletin Series I, No. 9. 17 p. 